\title{
Enunciación
}

http://revistas.udistrital.edu.co/ojs/index.php/enunc

DOI: http://dx.doi.org/10.14483/udistrital.jour.enunc.2016.2.a10

enunciación

Autor InVITADo

\section{La lectura: puerta de entrada a los bosques narrativos}

\section{The Reading: Entrance to the Fictional Woods}

\author{
Diógenes Fajardo Valenzuela ${ }^{1}$
}

Para citar este artículo: Fajardo, D. (2016). La lectura: puerta de entrada a los bosques narrativos. Enunciación, 21 (2), $314-329$.

\begin{abstract}
Resumen
Los grandes escritores siempre han reconocido la importancia de la lectura como punto de partida de sus exitosas carreras literarias. El objetivo de este artículo es, por un lado, justificar el acercamiento de los niños a la literatura como parte fundamental de una educación para la aceptación del otro con tolerancia y respeto a sus creencias y narrativas; y por otro, analizar el proceso de lectura, entendida como puerta de entrada a los bosques narrativos en donde debemos participar activamente. La lectura de solo imágenes se inicia desde el vientre materno. Luego se combina con la palabra, de suerte que tenemos libros ilustrados y los llamados libros-álbum, para finalmente llegar al libro conformado tan solo por el texto escrito. La invitación, realizada con la ayuda de Umberto Eco, es la de llevar al niño a bosques narrativos donde pueda jugar a ser copartícipe en la creación de la historia como también a perderse en ella.
\end{abstract}

Palabras clave: lectura, educación, literatura infantil, clásicos, libro-álbum, lectura literaria.

Muy sintomáticamente, dos grandes escritores en alguna época también grandes amigos, y ambos galardonados con el Premio Nobel de Literatura, al narrar sus vidas han hecho un agradecido reconocimiento a quienes los iniciaron en el trabajo de "deletrear los enredos de enredos de los enredos", según la fórmula poética de César Vallejo (1985, p. 24). El primero de ellos, García Márquez (1981), cuenta:

Una de las personas inolvidables en mi vida es la profesora que me enseñó a leer a los cinco años. Era una moza bonita y sabia que no pretendía saber más de lo que podía, y era tan joven que con el tiempo acabó por ser más joven que yo. Fue ella quien nos leía en clase los primeros poemas que me pudrieron el seso para siempre.

El segundo, como ya podrán haberlo previsto, es el autor de la encomiada obra La ciudad y los perros. Vargas Llosa comenzó su discurso de aceptación del Nobel con esta evocación:

Aprendí a leer a los cinco años, en la clase del hermano Justiniano, en el Colegio de la Salle, en Cochabamba, Bolivia. Es la cosa más importante que me ha pasado en la vida. Casi setenta años después recuerdo con nitidez, cómo esa magia, traducir las palabras de los libros en imágenes, enriqueció mi vida, rompiendo las barreras del tiempo y el espacio (p. 1).

1 Universidad Nacional de Colombia. Correo electrónico: dfajardov@gmail.com 
En estos dos testimonios eximios podemos ver un reconocimiento a todos los maestros que se dedican al mágico juego de crear mundos deslumbrantes con palabras e imágenes en esos primeros años tan importantes para sensibilizar a los niños, de suerte que estos puedan apreciar la belleza de la naturaleza y despertar su curiosidad que los mueve a descubrir los secretos de la vida.

En mi experiencia, debo confesar que también soy deudor de aquel maestro de escuela primaria que una mañana de clase capturó toda mi atención con su relato oral, sin ninguna ayuda audiovisual, y sin que yo recuerde mención alguna a la procedencia del cuento. Logró que mi imaginación fuera construyendo paso a paso la historia de un pobre jorobado que muere, a causa de una espina de pescado. Y como es necesario echarle la culpa al vecino, comienzan las sucesivas peripecias para deshacerse del muertico. La conclusión no puede ser menos dramática: el muerto revive y se evita así el castigo de quienes se creían culpables de su deceso. No puedo precisar si fue la gran habilidad narrativa oral del maestro, o la concatenación de la trama lo que hizo que las imágenes construidas a partir de las palabras del relato se fijaran hondamente en mi memoria. Ello me permitió, muchos años más tarde, descubrir -asombrado- que el maestro había cautivado mi atención con la "Historia del Alfayate y el jorobado y el médico judío y el Mubashir y el cristiano corredor de comercio", que se narra en las noches 25, 26 y 27 del libro Las mil y una noches. Quizá este maestro, cuyo nombre se borró de mi memoria, haya sido en cierta forma el responsable de que me preocupara más por una educación humanística que por una educación orientada hacia el beneficio económico.

Precisamente, la reconocida filósofa norteamericana, Martha C. Nussbaum, en su discurso de aceptación del doctorado honoris causa que le otorgó la Universidad de Antioquia, a finales de 2015, ha vuelto a insistir en la importancia de prestar mayor atención a la teleología de la educación. Desde el título de su intervención, "Educación para el lucro, educación para la libertad", Nussbaum (2015) plantea la disyuntiva ante la cual se encuentra la democracia en estos tiempos de profunda "crisis mundial de la educación". Señala que fundamentalmente hay dos tipos de educación si atendemos a su finalidad: el primero, busca sencilla y Ilanamente la obtención del mayor lucro posible e insta a los países a "fomentar la rentabilidad a corto plazo mediante el cultivo de capacidades utilitarias y prácticas" (2013, p. 20). El segundo tipo persigue una educación para la libertad en donde se fomenten las habilidades que permitan capacitar al estudiante para "pensar de manera crítica" y, así, "trascender las lealtades locales y acercarse a los problemas mundiales como un 'ciudadano del mundo'; capaz de imaginar comprensivamente la situación del otro" (2015). Congruentemente, la lectura crítica implica la disposición de entender la otredad, de estar dispuestos al cambio, procurando librarnos de prejuicios y dogmas que impiden otro acercamiento a la realidad.

Hasta aquí podríamos simplemente deducir que se trata del planteamiento académico de una norteamericana crítica de su propio sistema educativo. Pero hay dos puntos que quisiera resaltar de su análisis ante el hecho de que "en casi todas las naciones del mundo se están erradicando las materias y las carreras relacionadas con las artes y las humanidades" (Nussbaum, 2013, p. 20). El primero responde la pregunta: ¿Desde cuándo debe acercarse el estudiante a este universo que los mismos gobiernos quieren proscribir? La respuesta de psicólogos y educadores es casi unánime: desde la más tierna edad. Por tanto, debe formar parte del currículo apenas los infantes ingresan al sistema educativo. La segunda: ¿Cómo se logra una educación para la libertad que promueva valores como la tolerancia, el respecto a las creencias y formas de vida de los otros? La respuesta llana y precisa de Nussbaum no deja dudas: "[...] por medio de la enseñanza de la literatura y las artes" (2015), incluyendo, por supuesto aquellas obras de la más alta calidad, que algunos consideran deben reservarse para una selecta minoría. 
En consecuencia, si queremos hacer resistencia a la tendencia mundial de suprimir las humanidades y las artes de los programas educativos, debemos argüir en pro de su permanencia en los planes de estudio en todos los niveles. E insistir que, como lo plantea nítidamente Ana María Machado (1994), leer es parte ya de esa resistencia. Si en verdad las humanidades cumplen su misión, deben formar nuevos ciudadanos capaces de

[...] aprender a ver a otro ser humano no como una cosa sino como una persona completa. Por supuesto que este no es un logro automático: debe ser promovido por una educación que refine la capacidad de pensar acerca de lo que puede ser la vida interna de otro, y también para entender por qué no es posible captar plenamente ese mundo interior, por qué una persona es siempre hasta cierto punto un enigma para el otro. (Nussbaum, 2015).

También el filósofo francés Gilles Lipovetsky (2016) sostiene que la educación tiene un papel fundamental en la conformación de una nueva ciudadanía en la actualidad. Recomienda ofrecer a niños y jóvenes una educación digna que "incluya otras perspectivas diferentes a las de ganar dinero y consumir". Y en contracorriente con quienes están recomendando la exclusión de las humanidades del sistema educativo formal, constata que en nuestros días "la educación artística es insuficiente". Dice:

[...] hemos considerado que la educación artística es lo último: primero las matemáticas, las ciencias, un poquito de arte, ahí salpicado... Y creo que es un error. Es un error porque el hombre del mañana tendrá cada vez más aspiraciones estéticas: el amor por la belleza y la necesidad de expresarse.

Según Yolanda Reyes (2007),

[...] en esa arista que mezcla lo universal con lo particular y que nos permite reconocernos, diferenciarnos y construirnos mediante el diálogo con las páginas de la cultura, se encuentra la justificación profunda para incluir la formación literaria en la canasta familiar de nuestros niños, como alternativa de nutrición emocional y cognitiva y como equipaje básico para habitar mundos posibles, a la medida de cada ser humano (p. 13).

Y aquí llegamos al objetivo de esta ponencia: justificar el acercamiento de los niños a la literatura con el fin de que tengan una relación diferente con el mundo. El conocimiento de otras formas de ser, pensar y sentir permitirá una mejor comprensión y aceptación de las diferencias. El enigma que cada ser encierra en sí mismo no podrá develarse, así sea parcialmente, sino con la ayuda de la imaginación narrativa. Y a este reino solamente podemos acceder por medio de la lectura de textos narrativos. Umberto Eco (1997) nos invita a pasear por el bosque narrativo, metáfora útil "no solo para los cuentos de hadas, sino para todo texto narrativo. Hay bosques como Dublín, donde, en lugar de Caperucita Roja podemos encontrarnos con Molly Bloom, o como Casablanca, donde nos encontramos con Ilse Lund o Rick Blaine" (p. 14).

Quisiera detenerme aquí para llamar la atención sobre la forma en que el autor italiano ha dado un giro de tuerca y nos lleva de la literatura infantil al mundo de la imaginación narrativa del adulto. En realidad, se trata de diversos receptores, pero de una misma naturaleza literaria. Me explico: no existe en verdad una literatura infantil, ni una literatura adulta, ni una literatura femenina, ni una literatura masculina. Existe simplemente la literatura con una orientación hacia los infantes, los mayores, las mujeres o los hombres. El destinatario es un criterio muy usado para emplear esas diversas categorías. Porque como lo demuestra Wolfgan Iser en The Act of Reading, todo texto implica una relación dialéctica entre el texto, el lector y su interacción (1980, p. x). Es más, el mismo texto estructura un lector implícito que de ninguna manera debe 
confundirse con el lector real. Por su parte, Eco habla del lector modelo, entendido como "un lector-tipo que el texto no solo prevé como colaborador sino que incluso intenta crear" (1997, p. 17). También el autor italiano enfatiza que "el lector modelo de una historia no es el lector empírico"

Por otra parte, según lo señalara Roland Barthes (1978), las etiquetas como literatura infantil, juvenil, femenina, etc., básicamente sirven para facilitar el consumo. Es el mercado el que fomenta esa división de la literatura de acuerdo con los clientes potenciales. Por ello, Machado confiesa: "Yo no escribo para niños. Los editores, sí, publican mis libros para niños, les ponen ilustraciones, tipografías grandes" (1998, p. 32). Pero, en verdad, la naturaleza literaria es la que permite que un texto narrativo supuestamente perteneciente al mundo infantil sea tan provechosamente visitado por otra clase de públicos muy diversos. El principito, de Antoine de Saint Exupéry, es un buen paradigma de esta posibilidad. Eco (1997) nos proporciona otro ejemplo: Las aventuras de Pinocho. Según su lectura, el íncipit del cuento de Pinocho es muy complejo porque por una parte parece estar dirigido a mis pequeños lectores. Pero por la otra,

[...] ese principio es un guiño para lectores adultos. ¿Es posible que el cuento también sea para ellos? ¿Y que ellos deban leerlo de manera diferente, pero para entender los significados alegóricos del cuento deban fingir que son niños? [...]. Quizá Collodi quería hacer un doble juego, y sobre esta sospecha se basa gran parte de la fascinación de este pequeño gran libro. (p. 18).

Esta hipótesis de Eco supone un gran cambio también, pues en cierto sentido es preciso desacralizar la literatura para bajarla de su pedestal de algo serio, orientado solo a un público adulto y situarla en un plano de comunicación en donde los participantes (autores y receptores) hacen un uso singular del lenguaje en el contexto de una cultura. Por motivos prácticos, al igual que el semiólogo italiano, me limitaré a la narrativa, lo cual no quiere decir que los demás géneros no formen parte de ese mundo del arte creado mediante las palabras o que no pueden ofrecerse a los niños. "No hay nada importante en la vida que no pueda hablarse con un niño' [...], el paso del tiempo, la imaginación, las posibilidades del lenguaje" $(\text { Ortiz, 2016) })^{3}$.

Si, según lo postula Borges (1974), "el hecho estético está en relación con la inminencia de una revelación que no se produce" (p. 635), es función del maestro aproximarse a la forma de leer del niño, a la manera en que entienden lo que leen, a la preocupación por la respuesta estética de su parte. Responder a la pregunta: ¿Cómo leen los niños la literatura infantil?, es enfrentarnos a una realidad mucho más compleja,

[...] puesto que estas obras no solo hacen uso de recursos verbales, sino muchas veces utilizan recursos visuales -ilustraciones- o recursos sonoros -audio libros o libros didácticos-. En estos libros la historia ya no se cuenta únicamente por medio del texto escrito, sino que se utilizan otras herramientas que también "cuentan". (Escobar, 2011, p. 50).

Los niños leen con una mayor apertura hacia los mundos posibles, con la imaginación como guía, sin preocuparse por establecer límites entre la ficción y la realidad. ¡Que de eso se preocupen los adultos y los

2 El lector empírico somos nosotros, ustedes, yo, cualquier otro, cuando leemos un texto. El lector empírico puede leer de muchas maneras, y no existe ninguna ley que le imponga cómo leer, porque a menudo usa el texto como un recipiente para sus propias pasiones, que pueden proceder del exterior del texto, o este mismo se las puede excitar de manera casual" (Eco, 1997, p. 16).

3 Este poeta español escribió Lecciones de poesía para niños y niñas inquietos con la finalidad de iniciarlos en ese mundo maravilloso y así poder leer con gusto unos poemas. Mediante el humor se burla de quienes piensan que "la poesía infantil es rimar gatito con perrito o quesito con ratoncito. Ni los niños son tontos ni la poesía es una tontada" (2016, p. 22). 
profesores de literatura! El Ilamado "pacto ficcional con el autor, lo que Coleridge Ilamaba 'la suspensión de la incredulidad', no requiere de un mayor esfuerzo de parte de los niños lectores. Ellos están siempre dispuestos a aceptar que 'lo que se les cuenta es una historia imaginaria'" (Eco, 1997, p. 85), y por tanto, si es verdad o no, les es completamente irrelevante. ¿Qué importa si no es verdadero sino ficticio si lo realmente importante es que puedan reír y disfrutar la historia? He aquí el secreto de la fascinación de la ficción narrativa.

La ficción tiene la misma función que el juego [...] jugando el niño aprende a vivir porque simula situaciones en las que podría hallarse adulto. Y nosotros adultos, a través de la ficción narrativa, adiestramos nuestra capacidad de dar orden tanto a la experiencia del presente como a la del pasado. (Eco, 1997, p. 145).

Por otra parte, es importante precisar que por texto narrativo no debemos entender solamente un texto escrito. De hecho, Eco -al explicar el título de su libro- introduce de paso un texto narrativo no escrito sino desplegado en su lenguaje cinematográfico al mencionar que en la película Casablanca podremos encontrar un texto narrativo que nos cuenta la historia de amor protagonizada por los actores Ingrid Bergman y Humphrey Bogart. Y no hay que olvidar que

[...] esa criatura que, agazapada en el vientre, escucha furtivamente las conversaciones de su madre, y en particular, la música de su voz que le llega, en estricto sentido literal, desde las entrañas, está inmersa desde entonces en la experiencia del lenguaje. (Reyes, 2007, p. 27).

Desde el punto de vista del destinatario es preciso aceptar que toda ficción narrativa exige una activa participación ya que "todo texto es una máquina perezosa que le pide al lector que le haga parte de su trabajo". La literatura puede verse "como la forma de develar los huecos que deja el autor para que el lector los llene", de forma que venga a "participar en la construcción de sentido" (Chambers, 2008, pp. 81-82). Esto implica que "el lector está siempre, y no solo como componente del acto de contar historias, sino también como componente de las historias mismas." (Eco, 997, pp. 9, 11). Por el acto de leer, se participa en el proceso de creación de las obras. En realidad no leemos un libro, sino que lo creamos con cada lectora que hacemos de él. Como lo afirma Borges:

[...] para el mismo lector el mismo libro cambia, cabe agregar, ya que cambiamos, ya que somos [...] el río de Heráclito, quien dijo que el hombre de ayer no es el hombre de hoy y el de hoy no será el de mañana. Cambiamos incesantemente y es dable afirmar que cada lectura de un libro, que cada relectura, cada recuerdo de esa relectura, renuevan el texto. También el texto es el cambiante río de Heráclito (p. 102).

Se comprende, así, que "cada ente literario esté condenado a una vida eterna, siempre nueva y siempre naciente, mientras viva la humanidad" (Reyes, 1962, p. 85). Para realizar este trabajo de coautoría y de incesante creación, el lector se enfrenta siempre a una nueva historia con lo que el autor de El nombre de la rosa denomina enciclopedia personal, conformada por todas las lecturas previas del sujeto lector. Con todo lo leído antes, llega a poner a funcionar esa máquina perezosa para obligarla a generar nuevos sentidos con cada lectura, con la multiplicidad de lecturas que imágenes y textos nos proponen como un desafío para construir, para crear el reino de la posibilidad. 


\section{LECTURA DE IMÁGENES}

Sin duda, este acercamiento a un lector-autor nos conduce a la consideración de la lectura como complejo proceso que implica variadas faces y una participación muy dinámica del sujeto-lector. La primera barrera que habría que superar es esa noción de lectura como un sencillo desciframiento de signos alfabéticos para conformar voces o palabras. Frente a esta convencional concepción mecanicista de la lectura, es preciso contraponer otra centrada en la comprensión de imágenes complejas de orden literal, pero también visual, metafórico, emocional.

Si aceptamos esta última forma de concebir la lectura, podemos concordar que su ejercicio se inicia desde la primera infancia (desde la etapa intrauterina hasta los seis años) y que paradójicamente, el infante, el que no habla, sí lee todo el contexto que lo rodea, en especial su relación con la madre, pues construye significados con muchos lenguajes que le permiten su desarrollo infantil. En este contexto,

[...] las primeras relaciones entre el bebé y su madre cobran crucial importancia como la matriz o el "nido" de todo acto de lectura, desde el más sencillo hasta el más sofisticado, pues, en el fondo, la "interpretación" no es más que ese juego de dos o más sujetos que se transforman mutuamente en el proceso de negociar sentidos. (Reyes, 2007, p. 25).

Ahora bien, el infante no solo percibe desde el útero ruidos y sonidos, sino que comienza a procesar sonidos lingüísticos asociados a la voz de la madre y a la lengua en que esta le hable. Y como esencialmente capta ritmos de ese lenguaje, patrones de entonación, características acentuales, etc., es preciso admitir que comienza así su acercamiento a la función estética del lenguaje.

El énfasis en el ritmo y la prosodia y la carga melódica que imprime la voz adulta al dirigirse a los bebés demuestra que portamos, como equipaje evolutivo de la especie, una cadencia que trasciende el uso utilitario del lenguaje y que, más allá del significado literal de las palabras, trasmite una experiencia estética. (Reyes, 2007, p. 28).

Para el infante, es todavía mucho más intensa esa experiencia de que el lenguaje en sí mismo es un fenómeno estético ${ }^{4}$. Imaginemos un caso en el que los padres no le hablan a su bebé, ni le cantan siquiera "Los pollitos", no lo curan mágicamente con el "Sana que sana...", ni le cuentan la historia de "La pobre viejecita". El resultado es completamente previsible: ese niño comienza a manifestar retrasos en su desarrollo sensorial, musical, verbal; le hacen falta las lecturas de la primera infancia.

Al contrario, si esos primeros maestros, los padres, se preocupan por el acercamiento del infante a ese mundo enigmático del lenguaje, lo prepararán para que se convierta en un experto lector de imágenes. El verdadero alistamiento para la lectura se inicia allí, en el ambiente que desde su concepción comienza a rodear al infante. Sin duda, cada generación viene marcada por énfasis en tal o cual lectura, dependiendo del auge y desarrollo tecnológico que se tengan en cada época. Así, por ejemplo, mi generación fue mucho más entrenada para las imágenes auditivas, gracias a la radio. Cuando niños escuchamos las lágrimas sensibleras de las madres que experimentaban verdaderas catarsis escuchando la radionovela cubana El derecho de nacer, de Félix B. Caignet. Mario Vargas Llosa (1981) recoge literariamente este periodo de auténtica pasión radioteatral en la obra La tía Julia y el escribidor. La abuelita responde la pregunta de su

4 "Si la literatura es expresión, la literatura está hecha de palabras y el lenguaje es también un fenómeno estético" (Borges, 1980, p. 102). 
nieto, Marito, sobre la razón de esa predilección explicándole que "es una cosa más viva, oír hablar a los personajes, es más real [...]. Y además, a mis años se portan mejor los oídos que la vista" (p. 113). En oposición a esa vieja generación, los nacidos con el nuevo milenio crecen en una cultura mucho más visual que antes, lo cual les brinda un esmerado entrenamiento en la lectura de imágenes visuales. Muchos de ellos inician su adicción a la televisión en brazos de las madres que los arrullan con las imágenes del programa -por desgracia casi siempre insulsas telenovelas- que ellas no se pierden porque, además de la distracción, les permiten soñar y vivir las cosas imposibles de la vida real. No es de extrañar, entonces, que años más tarde se conviertan en fanáticos seguidores de los libros de cómics o historietas. Grandes y chicos disfrutan de personajes provenientes del mundo de las historietas animados como los superhéroes de Marvel Comics a nivel popular (Spider-Man, Capitán América, Iron Man etc.), o las Aventuras de Tintín, o de Uzumaki Naruto. En otra dimensión estética, apreciarán El viaje de Chijiro (2001), de Hayao Miyazaki, o La tumba de las luciérnagas (1988), de Isao Takahata, obras divulgadas bajo el formato del manga o del anime ${ }^{5}$.

\section{LECTURA MIXTA: IMÁGENES Y TEXTO}

Una segunda etapa en el proceso de lectura se desarrolla cuando los niños, en el intervalo de los 3 a los 6 años, comienzan a familiarizarse con libros que combinan las imágenes visuales con algunas palabras escritas. Cuando se traza la historia de estos libros, se anota que Orbis Sensualium Pictus u Orbis Pictus del monje checo Jan Amos Komenski, debe ser considerado como el primer libro ilustrado para niños. Con Comenio, nombre latinizado de Komenski, la educación tuvo a un gran orientador pues centró todo el proceso en los dos sujetos fundamentales: el niño y el maestro. Su preocupación mayor fue la de lograr que la educación respondiera a los interrogantes que planteaban las relaciones más significativas entre: el ser humano y el mundo que lo rodea, el individuo y la sociedad, la educación general y las didácticas particulares. Sus ideas encarnaron en propuestas novedosas para hacer germinar las potencialidades del niño en todos sus niveles. Los maestros conocen el gran aporte que Comenio realizó a la educación por medio de la divulgación de sus ideas pedagógicas orientadas a lograr la enseñanza de todo para todos, sin distinción de clases sociales ni de géneros. Desde la aparición de su obra, El mundo pintado, los niños comenzaron a familiarizarse con dos códigos diferentes: el pictórico y el lingüístico. Y si bien en algunos casos se trata de dos códigos disfrazados que en realidad obedecen a uno solo, poco a poco, tanto autores como lectores se hicieron más conscientes de que no se trataba tan solo de repetir la misma historia bajo los dos códigos, sino de lograr una autonomía que luego hiciera posible un diálogo entre ellos para construir significados en forma compartida.

Para comprender mejor este proceso evolutivo, Marantz (2005) propone que lo imaginemos como una línea

[...] que en cada uno de sus extremos tiene una novela típica, es decir un libro cuyas páginas están exclusivamente llenos de palabras impresas. Al otro extremo de esta línea imaginaria, hay un libro totalmente carente de texto, uno que transmite su mensaje (generalmente un cuento) utilizando solo imágenes. En el medio de la línea hay volúmenes que contienen una sola ilustración (en la portada), algunos que emplean viñetas al principio o al

5 Manga es el término en japonés para designar las historietas y el estilo del dibujo que las acompaña. Junto con la tradición norteamericana y la francobelga, se constituye como un referente obligado al hablar de la industria editorial de las historietas en el mundo. Anime es la adaptación japonesa de la palabra animación y se usa hoy en Occidente precisamente para referirse al trabajo de animación hecho en Japón. El anime se dirige a todos los públicos desde el infantil hasta el adulto y abarca una gran variedad de temas y de géneros. 
final de cada capítulo, otros que tienen imágenes ocasionales a página completa... y unos pocos que insertan una gran variedad de ilustraciones a lo largo del libro (p. 17).

Si Comenio es el creador del libro ilustrado, Randolph Caldecott es el verdadero padre del Ilamado libro-álbum, pues en sus obras

[...] hay una yuxtaposición de palabras e imágenes, algo que jamás había sucedido. Lo que no está en el texto está en las imágenes y viceversa, es un efecto recíproco que va y viene en ambas direcciones, en suma es la invención del libro-álbum. (Green, 2005, p. 23).

Este nuevo género se diferencia claramente del libro de cuentos conformado solo por un código lingüístico o del libro ilustrado que tiene ya una larga tradición -aún vigente- y a la cual se han vinculado artistas famosos como Gustave Doré, Henri Matisse, Salvador Dalí, Pablo Picasso, Joan Miró, Frank Moser, Fritz Eichenbert, entre otros. Lo que descubre Caldecott, con obras como The Diverting History of John Gilpin, Hey Diddle Diddle o The Queen of Hearts, es que se pueden crear libros en donde las ilustraciones no sirven solo para ampliar lo que dicen las palabras sino que también requiere de esas imágenes "para esclarecer el texto e, incluso a veces, para tomar su lugar. En un libro-álbum tanto las palabras como las imágenes son leídas. Y naturalmente este enfoque conlleva a usar menos palabras, o a no usarlas del todo" (Shulevitz, 2005, p. 10).

Según Marantz, este nuevo género del libro-álbum se caracteriza por: a) su concepción como unidad interdependiente, de forma tal que no se puede entender el texto sin las ilustraciones ni estas sin aquel; b) su naturaleza narrativa, en donde el cuenta-cuentos es reemplazado por el ilustrador y "las imágenes se convierten simbólicamente en la voz que comunica ciertas cualidades especiales del significado que el lenguaje con frecuencia no puede transmitir"; c) la confluencia de dos formas artísticas: la visual y la literaria, y finalmente, e), su carácter artesanal en donde se resalta más el cómo se comunica el autor que el qué comunica (Shulevitz, 2005, pp. 19 y 20). Teresa Colomber (2005) Ilama la atención sobre el arte combinatoria que singulariza al libro álbum así como la posibilidad de tener un destinatario de muy variados intereses:

Lo que caracteriza a los álbumes es que utilizan dos códigos -la imagen y el texto- para contar su historia. Este recurso puede utilizarse con propósitos distintos, y la obra resultante puede dirigirse a lectores de diferentes edades. Pero sin duda, uno de los grandes campos de aplicación de este género ha sido la creación de libros para primeros lectores (p. 41).

El trabajo iniciado por Caldecott pronto tuvo eco en artistas contemporáneos que compartían su interés por comunicar historias primordialmente por medio de la ilustración. Al conocer el trabajo realizado por Caldecott en el libro Old Christmas, de Washington Irving, publicado en 1875, el ya afamado escultor de madera Edmund Evans consideró que "Randolph Caldecott era la persona indicada para hacer los novedosos libros-juguete que tanto había soñado" (Green, 2005, p. 23). El trabajo conjunto que realizaron se concretó en 1878 con la publicación de los primeros volúmenes de rimas y canciones de preescolar que inmediatamente tuvieron una gran acogida en el público lector. Y así se inició una época dorada de obras fascinantes para los extasiados ojos de niños y adultos que siempre encontraban algo nuevo y humorístico en sus libros-álbum. Como es de suponerse, la invención del libro-álbum no significó la inmediata desaparición de los libros ilustrados, pero sí se convirtieron en punto de referencia que permite apreciar la evolución que se estaba dando. Quizá uno de los casos más notorios sea el de Beatrix Potter. La historia 
de El conejo Pedro comenzó con ilustraciones en blanco y negro, pero muy pronto se reeditaron con imágenes a todo color.

Los dibujos de Potter enriquecen la anécdota, pero El conejo Pedro puede ser perfectamente comprendido sin ellos. La historia en su totalidad está contenida en las palabras, que no solo aportan la información necesaria, sino que también engloban las ilustraciones. (Shulevitz, 2005, p. 10).

Este proceso continúa aún en nuestros días y por ello quizá sea significativo que actualmente se ofrezca en el programa de escrituras creativas de la Universidad Nacional la posibilidad de conocer y producir un libro-álbum. Y a juzgar por los trabajos presentados no es nada fácil manejar ese doble código característico de un artefacto que supone, por consiguiente, dos miradas: la del artista plástico y la del artista de la palabra. Pero cuando se logra la confluencia de estas dos formas artísticas no hay duda alguna de la riqueza que representa el libro-álbum para niños y adultos.

\section{LECTURA DE TEXTO}

Muchos sistemas educativos priorizan la lectura de texto escrito y marginan los libros con imágenes. Creo que se debe llegar al texto pero no omitir la lectura de las solas imágenes o de estas acompañadas en algún porcentaje de texto. Si gradualmente pasamos del reino de la imagen al dominio de las palabras llegaremos al más sombroso de los inventos del hombre. Borges (1998) dice que todos los demás inventos son extensiones del cuerpo. Pero la invención del libro permite "una extensión de la memoria y de la imaginación" (p. 9). El lector de un texto configurado tan solo con palabras, obliga al lector a emplear mucho más su imaginación, puesto que debe ir conformando personajes, escenarios, acciones que comienzan a desfilar en su mente a medida que avanzan las páginas y se enfrenta al hecho estético. Por medio de su imaginación, cada lector va ilustrando el texto que lee y se convierte así en creador de una obra que jamás puede ser igual a la de ningún otro lector. Ni siquiera será igual si realiza una relectura porque recordemos que "cada vez que leemos un libro, el libro ha cambiado, la connotación de las palabras es otra. Además los libros están cargados de pasado" (Borges, 1998, p. 22).

Si aceptamos lo expuesto anteriormente sobre el complejo proceso de la lectura que conlleva un dinamismo tal que convierte a los lectores en autores que con cada lectura vuelven a crear los textos, tenemos que concluir que una de las principales funciones de la escuela es la formación de lectores capacitados y dispuestos a perderse en los bosques narrativos. Pensando con el deseo, los maestros quisieran que ese arduo proceso de la lectura se iniciase desde el hogar. Pero la cruda realidad es que no siempre reciben a los niños con esa preparación, con ese camino andado, por muchos motivos: falta de educación de los mismos padres, condiciones socioeconómicas muy difíciles, falta de acompañamiento al infante en su labor de descubrir el mundo. En reiteradas ocasiones, por el contrario, el maestro tiene que confrontar conductas nocivas que el infante ha aprendido en su hogar. No hay que olvidar, por ejemplo, que la violencia de género o la semilla del fanatismo se siembran siempre en ese contexto de lo familiar, lo íntimo, lo doméstico.

Y no queda más remedio que suplir la carencia o reiniciar procesos de formación que implican gradualidad según edad, atención al contexto sociocultural y a intereses individuales. En todo caso, el maestro debe tener en mente que, en cuanto a la lectura, debe tratar de propiciar 
[...] la oportunidad de un primer encuentro [con el libro], con la esperanza de que este pueda ser seductor, atractivo y tentador. $Y$ que pueda redundar en la construcción de un recuerdo, aunque vago, que perdure toda la vida. Y más aún, esperar que ese encuentro equivalga a una invitación para la posterior exploración de un territorio muy rico, cuando el lector ya lea por su propia cuenta. (Machado, 2004, p. 19).

Además de esto, el lector se debe aventurar por los bosques narrativos sin la guía del maestro.

Para conseguir que este encuentro sea eficaz y duradero, es preciso que la escuela deje de ser sinónimo de disciplina y aburrimiento. Todo lo contrario, el niño debe experimentar que el tiempo en la escuela es de juego creativo, de retos a su imaginación de alegría por los logros alcanzados. Es preciso "partir de la confianza de las posibilidades imaginativas de los niños, en sus capacidades para manejar lo novedoso, para construir y pensar mundos posibles" (Castrillón, 2010, p. 27). Según, Lezama Lima (1969), "solo lo difícil es estimulante" (p. 9). Por ello hay que no caer en la tentación del facilismo del consumo esclavizante propuesto por la industria del entretenimiento en donde la lectura es vista "como un medio más de esparcimiento y de recreación intrascendente". Por el contrario, se debe ofrecer a los estudiantes obras en "las cuales se pueda observar la forma en que el autor desafía al lector, lo estimula, lo reta y lo impulsa en su crecimiento como lector y como ser humano" (Castrillón, 2010, p. 27). Hay ciertas características en los niños que resultan extrañas para los adultos. Por ejemplo, el que no se cansen de oír o de leer la misma historia en repetidas ocasiones. Y no dos o tres veces nada más. El adulto es quien se cansa con la repetición, no los niños. A ellos lo que les importa es que la historia sea bien contada. Quizá experimentan algo semejante a los griegos que aunque sabían ya el desenlace de la tragedia querían a volver a padecer su efecto catártico. Quizá también esa reiteración obedezca a la necesidad de memorizar lo escuchado porque, como bien lo expone Walter Ong (1987), "las sociedades orales deben dedicar gran energía a repetir una y otra vez lo que se ha aprendido arduamente a través de los siglos" (p. 47). Muy bien captó esta características de los niños la escritora brasileña Clarice Lispector (2011): "Los niños no leen de una sola vez: los niños aprenden de memoria y, aun sabiendo de memoria, releen con mucho de excitación de la primera vez" (p. 322). Otro ejemplo de la singularidad de los niños puede encontrarse en lo rigurosos que llegan a convertirse en el manejo de ciertas fórmulas para iniciar o acabar los cuentos o para el manejo de los tiempos verbales en sus juegos. "Había una vez un rey..." o "Juguemos a que yo era el rey y tú la reina".

Llegamos, así, a la lectura de textos literarios en propiedad. Machado (2004) sintetiza muy bien cómo debe ser el acercamiento del niño a estos libros: ante todo un rotundo no a la obligación de leer; en segundo lugar, propiciar un acercamiento a obras de calidad, entiéndase obras clásicas que jamás pasan de moda. En tercer lugar, creer que se puede fomentar el gusto por la lectura por medio de un sistema "que obliga a leer solo para hacer un examen es una forma de inocularle a cualquier el horror de los libros". En cuarto y último lugar, señala que "el primer contacto con un clásico en la infancia o en la adolescencia no tiene que ser con el original. Lo ideal sería tenerlo con una adaptación atractiva y bien hecha" (pp. 23-24).

Es preciso insistir en que la lectura no debe ser obligatoria. Hay que motivar la lectura no imponerla. Si lo hacemos es la mejor forma de conseguir que los estudiantes se vacunen en contra de la lectura. Para Borges (1980), "la idea de la lectura obligatoria es una idea absurda: tanto valdría hablar de felicidad obligatoria" (p. 107). Por fortuna en el archivo de la producción literaria de todos los tiempos, hay bastante de dónde escoger y, por tanto, de permitir que el mismo estudiante sea quien elija lo que le gustaría leer, bajo la guía del maestro. Para alimentar su espíritu, debe escoger entre lo mejor que se le presenta en la mesa, no de que tenga la oportunidad de quedarse con la basura. El arte de elegir es un aprendizaje que 
se inicia desde el momento en que la madre, en alguna ocasión, le pide al hijo que le diga qué texto quiere que ella le relea. Pero, en definitiva, por muy valiosa que sea una obra, no se puede obligar su lectura. La Comedia, de Dante, es un tesoro, pero es completamente admisible que alguien considere que este libro no le comunica nada. En estos casos, Borges (1980) aconseja: “Déjenlo de lado, que la literatura es bastante rica para ofrecerles algún autor digno de su atención, o indigno hoy de su atención y que leerán mañana" (p. 107).

La segunda recomendación de Machado es acercar al niño a los clásicos, "esos libros eternos que no pasan de moda". No hay razón para privar a los niños de tesoros de la humanidad que designamos con el nombre de clásicos so pretexto de que son difíciles o de que el autor no pensó en los infantes como su destinatario. De todos es conocido el planteamiento de Italo Calvino (1993) sobre el Por qué leer los clásicos. Ellos son los que nos permiten "entender quiénes somos y adónde hemos llegado" (p. 19). Es comprensible que cada persona tenga una noción diferente de lo que entiende por clásico. Pero es muy reconfortante comprobar que hay un sustrato común, compartido por los mejores autores, en la definición de los clásicos. Podría expresarse, según Steiner, que un clásico "nos interroga cada vez que lo abordamos... ¿Has comprendido? ¿Has re-imaginado con seriedad, estás preparado para abordar las cuestiones, las potencialidades del ser transformado y enriquecido que he planteado?" (1998, p. 32). Calvino (1993) expresa algo similar al afirmar que "un clásico es un libro que nunca termina de decir lo que tiene que decir" (p. 15). Y Borges (1974) asegura que clásico es el libro que se lee "como si en sus páginas todo fuera deliberado, fatal, profundo como el cosmos y capaz de interpretaciones sin término" (p. 773). El acercamiento de los niños y a los jóvenes a los clásicos constituye una riqueza porque "le dan una fuerza a la experiencia futura, proporcionando modelos, contenidos, términos de comparación, esquemas de clasificación, escalas de valores, paradigmas de belleza" (Calvino, 1993, p. 14).

La última observación de Ana María Machado tiene que ver con la forma de acercar a los niños a las obras clásicas. Permítanme aquí narrar una anécdota personal al respecto. Tuve en alguna ocasión una alumna de literatura que tomó conmigo un seminario sobre Don Quijote ofrecido aquí en la Universidad Distrital. Como era de esperarse, este curso tenía como objetivo la lectura de la obra magna de la lengua española. Y las reuniones del seminario debían facilitar esa lectura, complementar los hallazgos de sentido hechos por los estudiantes, responder algunas de sus dudas. Pero, empleando la expresión de antaño, para mal de mis pecados, al cabo de algunos años y por esa red infinita de causalidades que desconocemos y que llamamos azar, me enteré de que esa alumna del seminario, convertida en profesora de un prestigioso colegio bogotano, había mandado a leer El ingenioso hidalgo Don Quijote de la Mancha, en su versión original a los alumnos del cuarto grado de primaria. Creo que en aquella ocasión no tuvimos a mano la orientación que da la autora brasileña para evitar experiencias nefastas como la anterior:

El primer contacto con un clásico, en la infancia o en la adolescencia, no tiene que ser a través del original. Lo ideal sería tenerlo con una adaptación atractiva y bien hecha. Incluso podría aceptarse que navegar por los clásicos no significa leer los libros. El cine también nos ha dado buenas películas inspiradas en ellos, en versiones más o menos fieles, que no pueden ser descartadas como una posibilidad de contacto con ese tesoro. (Machado, 2004, pp. 24 y 98).

Por supuesto que se puede acercar al niño a la obra cumbre de la lengua castellana pero atendiendo a un proceso de lectura y a una verdadera iniciación para sentir con el corazón, para percibir la belleza que a cada instante nos rodea. La vida me dio la oportunidad de tener un público cautivo con el cual 
experimentar que sí es posible el acercamiento provechoso a las historias del famoso hidalgo manchego a una temprana edad: mis nietos. Y cómo poderles comunicar el deleite que experimentaron escuchando, por ejemplo, la que sucedió una tenebrosa noche en que el mismo intrépido caballero tuvo algo de miedo; ni qué decir de Sancho Panza que a causa de su profundo temor y espanto, le dio por hacer allí lo que "otro no pudiera hacer por él", ocasionando un gran disgusto a Don Quijote quien vio en ello que "la mucha conversación que tengo contigo ha engendrado este menosprecio" (De Cervantes, 2005, DQ, I, Cap. XX, pp. 185-186). Y ¿cómo no disfrutar de la aparición de Dorotea y la invitación que le hacen para que represente el papel de princesa Micomicona (el solo nombre despierta la risa de los infantes) después de conocer la treta que el cura y el barbero habían ingeniado para sacar a Don Quijote de Sierra Morena? Allí los niños disfrutan al imaginar al cura travestido como primer candidato para representar a Micomicona y al barbero con barba postiza, ante la inminencia de que se le caiga y quede al desnudo su verdadera identidad.

Para lograr un acertado acercamiento a los clásicos de la literatura, como Don Quijote de la Mancha, es preciso tener mucha claridad sobre cuál debe ser la función de los padres y de los maestros. Creo que en esencia deben fomentar lo que Bajtín (1981) Ilamó la imaginación dialógica. Esta implica que el maestro no sea simplemente un interlocutor o transmisor del sentido de los textos, sino alguien que "entienda que los estudiantes pueden ayudar a construir el conocimiento desde su saber y desde sus intereses" (López, 2013, p. 17). Quizá este hecho es que ha llevado a plantear que "el gran reto para los que ejercemos la docencia en el campo de la literatura [es] enseñar la necesidad de la literatura, no la literatura como un cúmulo de observaciones" (Jurado, 2004, p. 274). Con mucha razón Yolanda Reyes (2013) nos dice: "[...] necesitamos la literatura porque la experiencia de los demás nos ayuda a entender cómo lo hicieron otros, para emprender la antigua tarea del 'conócete a ti mismo' y 'conoce a los demás' y para abrir las puertas del reino de la posibilidad" (p. 68).

El papel del maestro en este proceso es decisivo "no como el que enseña (algo tan difícil hoy y tan imposible, insistamos), sino como quien está dispuesto a interactuar con el estudiante a partir de sus dilemas y de su búsquedas, y también como provocador para la búsqueda" (Jurado, 2004, p. 273). La función del maestro debe ser la de enseñar a aprender, alejado de la fiel ortodoxia y mucho más cercano al campo de la heterodoxia. La literatura siempre enseña que la realidad es mucho más compleja que lo que a primera vista parece y que cuanto más se aferra alguien a su verdad, más provoca la risa de Dios "porque el hombre piensa y la verdad se le escapa. Porque cuanto más piensan los hombres más lejano está el pensamiento de uno del pensamiento de los otros" (Kundera, 1987, p. 172). Si el maestro enseña a dudar de las certezas, logrará desarrollar "la capacidad del alumno para vivir la experiencia de la obra literaria, para reconocer y valorar su propia evocación personal como producto de su actividad creativa, para reflexionar sobre la obra y para analizar críticamente su reacción emocional ante la misma" (Dubois, 2001, p. 25).

Conocer mundos imaginados al alcance de nuestros ojos es la magia de la literatura. $Y$ hacer que los estudiantes aprendan a disfrutar de esa posibilidad es el reto del maestro de literatura. Su oficio privilegiado es, básicamente, leer. Y si ve en la lectura una forma de felicidad, podrá decir con el autor de El jardín de los senderos que se bifurcan: "Que otros se jacten de las páginas que han escrito / a mí me enorgullecen las que he leído" (Borges, 1974, p. 1016). La finalidad de sus lecturas debe ser compartirlas con los estudiantes. Debe tomar un libro y conseguir que sus estudiantes lo perciban como un objeto mágico, como una lámpara de Aladino, que de pronto nos revela un mundo lleno de misterios por descubrir, de viajes por realizar, de respuestas enigmáticas para nuestra triste condición mortal. Esa aventura se inicia desde el momento en que el estudiante toma en sus manos el libro y se encuentra con el arte de la cubierta que lo 
invita a irse de paseo por el bosque narrativo con el fin de ver paisajes interesantes, encontrarse con seres desconocidos, plantearse preguntas que resuelvan sus dudas ${ }^{6}$

En este momento el maestro debe ser "una voz que cuenta, una mano que inventa palacios y arquitecturas imposibles; alguien que abre puertas prohibidas y que traza caminos entre el alma de los libros y el alma de los lectores" (Reyes, 2013, p. 69). Por último, es preciso señalar que para lograr el acercamiento a la lectura y a la literatura, el maestro debe desplegar una inmensa creatividad para la planeación y realización de los talleres de lectura alrededor de un texto determinado. Y aquí es de suma importancia la formación recibida en la educación superior para que potencien sus capacidades para el acercamiento a un texto. Los maestros deben ser verdaderos actores: con formación en la modulación de la voz para la caracterización de personajes, con la capacidad de crear expectativas, de explicar el vocabulario desconocido, de motivar la participación del auditorio por medio de preguntas sobre lo leído e, incluso, deben ser excelentes guías en procesos artísticos como dibujo, pintura, figuras en papel, etc., con los cuales se puede culminar el proceso de lectura y el acercamiento a la literatura. Y en todo este proceso no hay modelos a seguir sino creatividad a desarrollar.

Ahora bien, ¿qué respuesta debemos buscar con el acercamiento a las obras de literatura? La misma que quería Lezama (1979) de parte de un escritor admirado:

Que se apodere de ese reto y disuelva la resistencia. Que destruya el lenguaje y que cree el lenguaje. Que durante el día no tenga pasado y por la noche sea milenario. Que le guste la granada que nunca ha probado, y que le guste la guayaba que prueba todos los días. Que se acerque a las cosas por apetito y que se aleje por repugnancia (p. 20).

Lo verdaderamente esencial es que el estudiante, con base en la lectura de los textos, pueda soñar y ser leal a sus sueños, para que en definitiva "vean en la literatura una forma de felicidad" (Borges, 1980, p. 108).

Para terminar esta ponencia quiero acudir a la novela Auto de Fe del nobel de literatura Elias Canetti. Se inicia con este espléndido diálogo entre un niño y un adulto que no me canso de releer:

-¿Qué haces aquí muchacho?

-Nada.

-Entonces, ¿por qué te quedas ahí parado?

-Porque...

$-¿$ Sabes leer?

-Pues sí.

-¿Cuántos años tienes?

-Nueve cumplidos.

-¿Qué preferirías: un chocolate o un libro?

6 Megan Lambert (2010) resalta la importancia de los paratextos, particularmente de la cubierta del libro, sobre todo en el caso de que la ilustración que allí se emplee no se repita en el libro. Y sugiere que se dé el tiempo y el espacio necesarios para que el estudiante reflexione sobre lo que va encontrando (p. 39). En el caso de la novela, la portada es normalmente parte de la decoración; en el libro-álbum, con frecuencia es parte integral de la narrativa: "If the cover of a novel serves as a decoration and can at best contribute to the general first impact, the cover of a picturebook is often an integral part of the narrative, especially when the cover picture does not repeat any of the pictures inside the book" (p. 36). 
- Un libro.

- ¿De veras? Estupendo. ¿Así que por eso estás aquí?

-Sí.

- ¿Por qué no me lo dijiste antes?

-Mi papá me regaña.

-Ajá. ¿Cómo se llama tu padre?

-Franz Metzger

- ¿Te gustaría viajar a otro país?

-Sí, a la India. Hay muchos tigres.

- ¿Y adónde más?

-A la China. Hay una muralla enorme.

- ¿Te gustaría escalarla?

-Es demasiado ancha y alta. Nadie puede escalarla. Por eso la construyeron.

-iCuánto sabes! Se ve que has leído mucho.

-Sí, leo siempre. Papá me quita los libros. Quisiera ir a una escuela china. Tienes que aprender cuarenta mil letras. Todas no caben en un libro. (Canetti, 1982, pp. 9-10).

Efectivamente, como lectores tenemos que quedar admirados de este ejemplar lector, que antes de ir a la escuela da un paseo por los escaparates de las librerías y que dice preferir un libro en vez de una deliciosa golosina. Allí, precisamente, es donde encuentra a Peter Kien, su interlocutor en este diálogo inicial, y a quien -a diferencia de su madre- considera como un profesor de verdad "porque tiene una bibliote$\mathrm{ca}^{\prime \prime}$. Para este niño de 9 años, la lectura lejos de ser un fardo pesado, una obligación, es una magnífica oportunidad de escapar del ambiente opresor, representado aquí por su propio padre, para buscar un reino de la libertad en donde puede imaginar muchos mundos reales e imaginarios dotados de extraordinaria riqueza cultural. Este niño por la lectura ha logrado convertirse, desde su más tierna edad, en un verdadero ciudadano del mundo y está ya preparado para aceptar que hay otras culturas, otras creencias, otras formas de ser humano, diferentes a las de su entorno inmediato. Encarnar a este imaginario crítico lector modelo en nuestras aulas es el desafío que debe aceptar el maestro, la maestra, de infancia y primeros años de escuela; además debe siempre recordar que, según el magisterio de García Márquez (1981), "un buen curso de literatura no debería ser mucho más que una buena guía de lecturas".

\section{REFERENCIAS BIBLIOGRÁFICAS}

Bajtín, M. (1981). The Dialogic Imagination: Four Essays. Edición de Michael Holquist. Austin: University of Texas Press.

Barthes, R. (1978). Análisis textual de un cuento de Edgar Poe. En: Lingüística y Literatura. Xalapa: Universidad Veracruzana.

Borges, J.L. (1974). Obras completas: 1923-1972. Buenos Aires: Emecé Editores.

Borges, J.L. (1980). Siete noches. México: Fondo de Cultura Económica.

Borges, J.L. (1998). Borges oral. Madrid: Alianza Editorial.

Calvino, I. (1993). Por qué leer los clásicos. México: Tusquets Editores.

Canetti, E. (1982). Auto de fe. Barcelona: Plaza \& Janés Editores.

Castrillón, S. (2010). Una mirada. Bogotá: Asolectura. 
Colomber, T. (2005). El álbum y el texto. En: C. Pifano (ed.). El libro álbum: invención y evolución de un género para niños (pp. 40-45). Caracas: Banco del Libro.

Chambers, A. (2008). Conversaciones: escritos sobre la lectura y los niños. México: Fondo de Cultura Económica.

De Cervantes, M. (2005). Don Quijote de la Mancha. Edición del Cuarto Centenario. Bogotá: Real Academia Española/ Asociación de Academias de la Lengua Española.

Dubois, M.E. (2001). Lectura, literatura, educación. En: Memorias VI Foro Educativo Distrital. Pedagogías de la Lectura y Escritura (pp. 20-26). Bogotá: Secretaría de Educación del Distrito.

Eco, U. (1997). Seis paseos por los bosques narrativos. Barcelona: Lumen.

Escobar M., D. (2011). Posiciones y posibilidades en torno a aquello que se conoce como literatura infantil. En: C.E. Acosta (ed.). Pensar la literatura infantil: Interpretación a varias voces (pp. 31-56). Bogotá: Universidad Nacional de Colombia.

García Márquez, G. (27 de enero de 1981). "La poesía al alcance de los niños". El País. Cali. Consultado en línea en http://elpais.com/diario/1981/01/27/opinion/349398006_850215.html (fecha consulta 15 de abril 2016)

García Márquez, G. (2002). Vivir para contarla. Bogotá: Norma.

García Montero, L. (2016). Lecciones de poesía para niños y niñas inquietos. Madrid: Visor.

Greene, E. (2005). Los libros-álbum de Randolph Caldecott: la invención de un género. En: C. Pifano (ed.). El libro álbum: invención y evolución de un género para niños (pp. 22-29). Caracas: Banco del Libro.

Iser, W. (1980). The Act of Reading: a Theory of Aesthetic Response. Baltimore: The Johns Hopkins University Press.

Jurado Valencia, F. (2004). Palimpsestos: la literatura en el contexto escolar. Literatura: Teoría, Historia, Crítica, 6, 269-296.

Kundera, M. (1987). El arte de la novela. Barcelona: Tusquets Editores.

Lambert, M. (2010). Gutter Talk and more. Picturebooks, Paratexts, Illustration and Design at Storytime. Children and Libraries. The Journal of the Association for Library Service to Children, 210, 36-46.

Las mil y una noches (1961). México: Aguilar.

Lezama Lima, J. (1969). La expresión americana. Santiago de Chile: Editorial Universitaria.

Lezama Lima, J. (1979). Esfera imagen. Barcelona: Tusquets Editores.

Lipovestsky, G. (27 de marzo de 2016). "Hoy nadie cree que la política pueda cambiar el mundo". Entrevista. El Tiempo, p. 3.

Lispector, C. (2011). Revelación de un mundo. Trad. Amalia Sato. Buenos Aires: Adriana Hidalgo.

López, Y. (2013). El placer de la lectura y la escritura en la escuela. En: Leer para comprender, escribir para transformar: palabras que abren nuevos caminos en la escuela (pp. 15-26). Bogotá: Ministerio de Educación Nacional.

Machado, A.M. (1998). Buenas palabras, malas palabras. Buenos Aires: Editorial Sudamericana.

Machado, A.M. (2004). Clásicos, niños y jóvenes. Bogotá: Grupo Editorial Norma.

Marantz, K. (2005). Con estas luces. En: C. Pifano (ed.). El libro álbum: invención y evolución de un género para niños (pp. 14-21). Caracas: Banco del Libro.

Ministerio de Educación Nacional (2013). Leer para comprender, escribir para transformar: palabras que abren nuevos caminos en la escuela. Bogotá.

Nussbaum, M. (2013). Sin fines de lucro: por qué la democracia necesita de las humanidades. Buenos Aires: Katz Editores.

Nussbaum, M. (2015). Educación para el lucro, educación para la libertad. Recuperado de: http://www.udea.edu.co/ wps/portal/udea/web/inicio/campanas/nussbaum-medellin.

Ong, W. (1987). Oralidad y escritura: tecnologías de la palabra. México: Fondo de Cultura Económica. 
Ortiz, M.P. (6 de mayo de 2016). Luis García Montero, poemas de carne y hueso. Entrevista a Luis García Montero. ElTiempo.com. Recuperado de: http://www.eltiempo.com/entretenimiento/musica-y-libros/ entrevista-con-el-poeta-espanol-luis-garcia-montero/16584706.

Reyes, A. (1962). Obras Completas de Alfonso Reyes. Vol. XIV. México: Fondo de Cultura Económica.

Reyes, Y. (2007). La casa imaginaria: lectura y literatura en la primera infancia. Bogotá: Grupo Editorial Norma.

Reyes, Y. (2013). La sustancia oculta de los cuentos. En: Leer para comprender, escribir para transformar: palabras que abren nuevos caminos en la escuela (pp. 63-70). Bogotá: Ministerio de Educación Nacional.

Shulevitz, U. (2005). ¿Qué es un libro-álbum? En: C. Pifano (ed.). El libro álbum: invención y evolución de un género para niños (pp. 8-13). Caracas: Banco del Libro.

Steiner, George. Errata: El examen de una vida. 1998. Madrid: Siruela.

Vallejo, C. (1985). Trilce. Bogotá: Oveja Negra.

Vargas Llosa, M. (1981). La tía Julia y el escribidor. Barcelona: Seix Barral.

Vargas Llosa, M. (2010). Elogio de la lectura y la ficción. Recuperado el 3 de mayo de 2015 de: http://www.nobelprize.org/nobel_prizes/literature/laureates/2010/vargas_llosa-lecture_sp.html

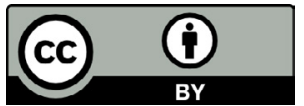

